\title{
Evolution of the Belarus-Russia Union State: FROM INTEGRATION TO ATTEMPTS OF INCORPORATION
}

\author{
Ewolucja Państwa Sojuszniczego Białorusi i Rosji: \\ od integracji do próby inkorporacji
}

\begin{abstract}
Russian-Belarus political and economic integration was one of the basic factors of the forming of the neo-authoritarian regime in Belarus. Russian economic support for president Lukashenko provided rapid winding up of democratic transformation in Belarus and preserved the administrative managing of the national economy.

For a long period, Belarus society had been stuck in the soviet style of political life. At the same time, such a style of the political system allowed Russia to keep Belarus in the sphere of its cultural and geopolitical influence. As a result, Belarus was hardly open to a constructive relations with the West, and regular political repressions kept the country isolated.

During the second period of Lukashenko's authoritarian rule, when the Russian policy got significantly more aggressive, the integration became destructive for Belarusian statehood. It is evident that Moscow has been trying to realize an idea to restore some kind of a new empire project, and uses different tools to achieve the goal. It might be said that integration is one of the mechanisms of a hybrid war which Russia wages against post-Soviet republics. Taking into consideration that Belarus has not developed full economic and political relations with the West, its economic and political system is widely dependent on Russia, which puts Belarus in a difficult, critical position.

The continuation of the integration with Russia may result in the loss of Belarus' independence. Even though Lukashenko has been able to resist Kremlin's insistence on the "deeper integration", Belarus is still a part of the Union State, and stability of the political and economic system of the country depends on Russian support. No doubt, Moscow will continue its policy of wider control and subordination of Belarus.
\end{abstract}

Keywords: Belarus, Russia, Union State, integration, incorporation

1 Dr Pavel USOV, Center for Political Analysis and Prognosis, Polskie Radio dla Zagranicy Redakcja Białoruska, e-mail: usovpavel@gmail.com 
Abstrakt: Rosyjsko-białoruska integracja, zarówno polityczna, jak i ekonomiczna, była jednym z podstawowych czynników, stojących u podstaw neo-autorytarnego reżimu na Białorusi. Rosyjskie wsparcie ekonomiczne dla prezydenta Eukaszenki zapewniło gwattowne zakończenie zmian demokratycznych na Białorusi i pozwoliło utrzymać odgórne zarzadzanie narodowa gospodarka.

Przez dtugi czas społeczeństwo białoruskie utknęło w sowieckim stylu życia politycznego. Jednocześnie taki właśnie styl polityczny umożliwił Rosji zatrzymanie Białorusi w swojej strefie wptywów, geopolitycznych $i$ kulturalnych. W rezultacie Białoruś prawie nie byta otwarta na konstruktywne relacje z Zachodem, a regularne represje polityczne utrzymywaty ten kraj w izolacji.

W drugim okresie autorytarnych rządów Łukaszenki, kiedy polityka Rosji stała się wyraźnie bardziej agresywna, integracja z Rosja stata zaczęła wyniszczać białoruska państwowość. Oczywistym jest, że Moskwa od jakiegoś czasu próbuje wcielić w życie idę odtworzenia swego rodzaju nowego imperium, i chwyta się różnych narzędzi, żeby osiagnać ten cel. Można powiedzieć, że taka integracja jest jednym z mechanizmów wojny hybrydowej, prowadzonej przez Rosję przeciwko postsowieckim republikom. Zważywszy na to, że Biatoruś nie rozwinęła w petni ekonomicznych i politycznych relacji z Zachodem, jej system ekonomiczny i polityczny jest w dużym zakresie zależny od Rosji, co stawia Białoruś $w$ trudnej, krytycznej pozycji.

Kontynuacja integracji z Rosja może zaowocować utrata niepodległości przez Biatoruś. Nawet jeśli Łukaszenko był w stanie oprzeć się naciskom Kremla na "głębsza integrację", Białoruś wciąż jest częścia Państwa Sojuszniczego, i stabilność politycznego i ekonomicznego systemu kraju zależy od rosyjskiego wsparcia. Bez watpienia Moskwa będzie kontynuować swoją politykę szerszej kontroli i podporządkowywania Białorusi.

Słowa kluczowe: Białoruś, Rosja, Państwo Sojusznicze, integracja, inkorporacja

\section{Introduction}

Belarus and Russia's integration project, known as the Union State of Belarus and Russia, is not just a geopolitical or economic process. The beginning of the integration dates back to the deconstruction of the democratic system in Belarus in the mid of 90 s with the subsequent undermining of the national culture and tradition of the country. In other words: on the one hand, the emerging of the Union State was possible thanks to the establishment and development of the authoritarian rule in Belarus. On the other hand, 25 years period of the existence of Lukashenko's regime was possible thanks to the close economic and political relations with Russia. 
Direct economic and political support had provided stability and security for the illiberal (Zakaria 1997: 22-43), non-democratic, neo-authoritarian (Usov 2004) system in Belarus.

Belarusian authority received almost unlimited access to the Russian economic resources: market, loans, cheap gas, and oil. In 2016, the International Monetary Fund had estimated general Russian economic support for Belarus at USD 106 bln., in the period from 2005 to 2015 (International Monetary Fund, 2016). According to Kremlin's statements, only in the period from 2011 to 2015. Also, Belarus received about USD 6 bln., credits, and annual duty-free oil deliveries during the same period of the amount of 18 million and 23 million tons. So, the economic profit for Belarus was about USD 22 bln. (Ткачёв, Фейнберг 2017). Such support allowed Belarus authorities to reject any economic reforms and developing relations with the West (EU in particular). Although Belarusian officials declared that Belarus is a bridge between the East and the West because the country is in between Russia and Europe (Лукашенко), Belarus had become a geopolitical appendage of Russia. Supporting authoritarian rule in Belarus, Russia had blocked any real movements of the Belarusian society toward democracy and free economics. What is important, there was a certain ideological content of the integration, based on Soviet tradition and the idea of reconstruction of the Soviet Union. "Sovietization" of the Belarusian cultural space and the society inevitably undermined national tradition and orientations of the Belarusian society. Before that, Belarusian nationalism had been a natural instrument of the distancing from Russia and fighting against authoritarianism.

So, the beginning of Lukashenko's rule was marked with the concentration of the soviet, anti-democratic, and anti-Western paradigm in Belarus, and it turned out to be one of the geopolitical successes of Russia. After dramatic events in Ukraine in 2014, "sovetskost" became one of the central ideas of the so-called "Russian world". Denationalized Belarusian society was unable to resist Russian information and political influence.

\section{Evolution of the Union State}

The model of the Union State has developed and transformed, paralleling authoritarian transformation in Belarus. The process of consolidation 
of the authoritarian regime in Belarus demanded political and economic support from the Russian side. Lukashenko made the idea of integration one of the main points of his political platform. Belarusian society had rather weak national orientations in terms of cultural and political peculiarities, and that allowed Lukashenko to easily manipulate public moods and expectations. Key changes in the constitution were introduced simultaneously with changes in the geopolitical orientation. However, one should bear in mind that in the mid-90s, the European direction for Belarus was elusive and unattainable. "Belarus was deprived of its political subjectivity in the eyes of more powerful others (meaning "West")" (Ackermann, Berman, Sasunkevich 2017: 22). So, geopolitical misbalance was set naturally, and as neither "Sovietized" population, nor "post-soviet" nomenclature offers real geopolitical choices and opportunities, the society followed the easiest way, towards Russia.

Moreover, during Yeltsin's, and early Putin's presidency Russia was considered a democratic country that could influence Belarus and democratize it in some way. That is why the integration was not considered a real threat to Belarusian independence, especially by the West. In 1995 Belarusian authority held the first referendum. Among the questions related to national symbols and the status of the Belarusian language, there was a question for the economic integration with Russia. Do you support the actions of the President aimed at the economic integration with Russia? (Центральная комиссии Республики 1995). According to official information, the integration with Russia was supported by $78 \%$ voters (Центральная комиссии Республики 1995). Of course, there is no reason to consider the referendum results as truthful. However, the rapidness of implementation of its results and general passiveness of the population proved the fact that Lukashenko's policy was supported by society.

Nevertheless, after the referendum, the Union State construction process gained additional energy. One year later, the treaty about the Formation of the Community of Russia and Belarus was signed. In 1997 the Treaty on the Union of Belarus and Russia (Информационно-аналитический портал 1), as well as The Charter of the Union of Belarus and Russia, were adopted. Basing on these documents, the Supreme Council and Standing Committee of the Union of Belarus and Russia were created. The Parliamentary Assembly of the Community transformed into the Parliamentary Assembly of the Union of Belarus and Russia. Between 1997 and 1998, the executive bodies of the Union and the general budget were formed, 
and the first Union programs were being developed and implemented. The Border and Customs Committees and the Security Committee were formed as well. In other words, the Union State's institutions' establishment occurred rapidly in 2 years. The formal process of the Union State's creation was completed in 1999 when the Treaty on the Union State's Creation was signed in Moscow. The treaty provided unification of the political, financial, and economic systems. (Информационно-аналитический портал 2).

Such an intensive process of integration is attributed to Lukashenko's extremely high desire and hope to become Boris Yeltsin's successor, or at least the head of the Union State. According to Boris Berezovskiy, who was one of the key persons in Yeltsin surroundings, this variant was seriously discussed in Moscow (Пригора), before those attempts were stopped by the liberal group of Russian politicians (Харитонов). That means Belarus became a hostage of the Lukashenko's ambitions. On the other hand, while Moscow effectively stopped Lukashenko, it did not get rid of the Union State project, proving Yeltsin's international policy successful, which was necessary for the consolidation of his power. Russian post-communist nomenclature tried to use Lukashenko as an instrument for keeping Belarus in the sphere of the Russian geopolitical influence. In the long run, such an approach turned out to be effective.

In some way, by keeping Belarus in its geopolitical influence area, Moscow tried to implement a new approach that was formed by the end of the 90s and in the early 00s, and defined by former Russian top liberal official Anatoliy Chubays. The core of this idea was Russia being a "liberal empire". It included an idea that the state should protect the Russian culture and Russian big business in post-soviet space (Венедиктов), basing on the liberal market model (СПС представил проект). The building process of the Union State was far from developing liberal values. Nevertheless, it corresponded to the idea of reconstruction of the empire.

After Vladimir Putin had become the President and consolidated his power with the help of the KGB-FSB group, the vision of the Union State by Russian elites changed. It is necessary to say that during the first years of Putin's rule over the Union State, relations with Belarus were not a priority. Moscow was involved in a war in Chechnya and its further reintegration and restoration, Kremlin had to centralize system of administration and reorganize the Federation, and also new elites were busy with the process of redistribution of economic resources. Only when authoritarian 
tendencies became dominant in Russian domestic policy and its international policy became more aggressive, Moscow saw a great geopolitical opportunity of developing the integration project. The evident sign of evolution was the appointment of Gregory Rapota, the general lieutenant of the former KGB, as a state secretary of the Union State in 2011. (Официальный сайт Постоянного)

\section{The military component of the Belarus-Russia integration}

It is necessary to emphasize that the key element of political integration was military and strategic cooperation. Belarus became an important part of the Russian security system. And if economic and political integration seemed to be unrealistic, strategic cooperation was very intensive even in the mid-90s. Eventually, it became one of the most important factors of Belarusian dependence on Russia.

Several fundamental strategic agreements were signed. These documents created legal grounds for further development of the Russian strategic interests in Belarus in the future. Among these document there were two which guaranteed the presence of the Russian military bases in Belarus:

A) Agreement between the Government of the Russian Federation and the Government of the Republic of Belarus on the procedure for completing the construction, use, and maintenance of the Baranavichy Unit of the Missile Attack Warning System, located in the territory of the Republic of Belarus, dated January 6, 1995. Hantsavichy Radar Station is an early warning radar that is run by the Russian Aerospace Defense Forces. It is designed to identify launches of ballistic missiles from Western Europe and can also track some artificial satellites;

B) Agreement between the Government of the Russian Federation and the Government of the Republic of Belarus on the use and maintenance of Vileika radio station located in the territory of the Republic of Belarus (January 6, 1995) (Электронный фонд правовой). The "Vileyka" VLF transmitter is the site of the 43rd Communications Center of the Russian Navy. It is an important facility for transmitting orders to nuclear submarines operating in the Pacific, Atlantic, and the Indian Ocean in the very-low-frequency range. The station is a part of the wireless location system of the Russian Military Fleet. 
C) Agreement between the Russian Federation and the Republic of Belarus on the joint use of military infrastructure facilities of the Russian Federation and the Republic of Belarus in the interests of ensuring the security of the States, signed in 1997 (the Agreement entered into force on 14 January 2000).

D) Treaty between the Russian Federation and the Republic of Belarus on Military Cooperation (19 December 1997), entered into force in 1999:

The parties shall carry out military cooperation in the following main areas:

- Defense policy and strategy;

- Convergence and unification of legislation in the field of defense, military construction and social protection of servicemen;

- Development of the state defense order, general programs of armament, production, and repair of military equipment;

- Creation of a regional grouping of troops (forces), planning of its use, operational and material support;

- unification of the management system of the regional grouping of troops (forces);

- maintenance and use of military infrastructure facilities of both states in accordance with the economic capabilities of the Parties and taking into account the military and political situation;

E) Agreement between the Russian Federation and the Republic of Belarus on the joint provision of regional security in the military sphere, of 19 December 1997.

The Agreement laid the foundation for the process of establishing "a regional grouping of troops (forces)", hereinafter referred to as "a regional grouping" - bodies of government and troops (forces) of the Armed Forces of the Republic of Belarus and the Armed Forces of the Russian Federation, as well as other military formations of the parties, located in peacetime or deployed in a period of threat in the region to repel possible aggression, and planned to be used according to a single concept and plan.

Since 2006, regular joint Russian-Belarus military exercises ("The West" and "The shield of the Union"), provided to the better command and operating of the regional group of the forces, have been held.

Evolution of the regional group of forces brought to the creation of the Joint Staff of the Regional Grouping of Forces (Joint Command of the Regional Grouping of Forces). In 2015, next exercises of regional groups of troops "Shield of the Union - 2015" took place, the development of a plan 
of exercises and their implementation were fully focused in the hands of Oleg Belokonev (Chief of General Staff of the Armed Forces of the Republic of Belarus).

In 2017, the strategic exercise, "West - 2017", was held in Belarus and Russia (10.200 people were involved in the territory of Belarus). Within the framework of the legend of the exercise, three aggressor states were invented, "Vesbaria" and "Lubenia", which represented Western countries, and "Veyshnoria" which was located in the territory of Belarus (Смирнов).

In September 2019, the Russian Federation hosted regular exercises as part of "The Shield of the Union 2019" (12.000 people). Further development of the military integration between Belarus and Russia took place even after Russian aggression in Ukraine and despite political contradictions between Belarus and Russia.

For example, in 2017, the Belarusian side ratified the Agreement between the Government of the Russian Federation and the Government of the Republic of Belarus on joint technical support of the regional grouping of troops (forces) of the Russian Federation and the Republic of Belarus. (Signed in 2016). (This agreement was based on the 1999 Union Treaty and the Agreement between the Russian Federation and the Republic of Belarus on the Joint Use of Military Infrastructure Facilities of the Russian Federation and the Republic of Belarus in the Interests of Ensuring the Security of States of 1997, which entered into force in 2000).

The integrated air defense system is another level of advanced military integration. In the early 1990s, the concept of a unified air defense system was implemented within the CIS. In the process of further disintegration of the post-Soviet zone and intensification of conflicts, Russia concentrated on the creation of a joint air defense system with Belarus.

On February 3, 2009, the Agreement between the Russian Federation and the Republic of Belarus on the joint protection of the external border of the Union State in the air space and the creation of a unified regional air defense system of the Russian Federation and the Republic of Belarus was signed.

The joint regional air defense system was to include task forces and military units of the parties located on the territory of the Republic of Belarus, Kaliningrad Special District, and western regions of the Russian Federation. The JRADS was supposed to include: aviation units - 5; anti-aircraft missile units - 10; radio engineering units - 5; electronic warfare 
units - 1 (ЕРС ПВО). The Commander of the Air Force and Air Defense of one of the parties, who is appointed by a joint decree of the Presidents of the Russian Federation and the Republic of Belarus on the proposal of the Defense Ministers of both countries, should head the JRADS on a rotating basis (ЕРС ПВО). Coordination of joint actions of the formations and military units assigned to the JRADS should be carried out from the central command post of the Commander-in-Chief of the Russian Air Force. During the period of threat, the joint command of the JRADS of the air defense system is established as a part of the joint command of the regional grouping of troops of the two countries (ЕРС ПВО).

Until 2012, the implementation of the agreements had been delayed, mainly by Belarus. On February 13, 2012, by his Decree No. 65, Lukashenko approved an agreement with Russia on joint protection of the external border of the Union State in the air space and the establishment of the JRADS of air defense.

In 2013, it was reported that Oleg Dvigalev, commander of the Air Force and Air Defense Forces of Belarus, was appointed commander of the JRADS.

So, as we see, despite the regular political conflicts between Moscow and Minsk, despite the war in Ukraine, Belarus continues tight strategic cooperation and integration with Russia, making Belarus state sovereignty fragile and vulnerable to the Russian influence. Such comprehensive cooperation and integration in security and military fields do not allow Belarusian authorities to provide any serious politics of distancing from Russia.

\section{Coerced integration}

Russian approach and vision of the integration have been changing with the general evolution of the Russian approach towards international policy and former Soviet republics. Belarus is now considered a necessary element of Russia's geopolitical expansion. During the year 2019, the integration process, which has already been a hidden mechanism of holding Belarus in the sphere of the Russian influence, has turned into the mechanism of the open pressure and realization of Kremlin's interests. Moscow has developed the wide-scale informational, political, and economic pressure on Belarus. 
The first demonstration of the new Russian strategy toward Belarus was related to the appointment of the new Russian ambassador in Belarus Mikhail Babich in 2018, who received the status of the special plenipotentiary of the Russian president. Babich was not a diplomat and belonged to the group of Russian "siloviks" (Писарев). From the very beginning, Babich behaved as if he were a "general-governor". He independently traveled over Belarusian regions, met with regional officials, businessmen, and politicians (Суботин). Moreover, the activity of the Russian embassy related to the extending of Russian influence and supporting pro-Russian organizations and centers increased tremendously. Russian ambassador became one of the main irritating factors for Lukashenko. His activity coincided with the Russian international pressure during 2019. After a serious confrontation between Minsk and Moscow, Mikhail Babich was withdrawn from the position of the ambassador and appointed as a deputy of the Minister of Economic Development of the Russian Federation. He became responsible for relations with CIS countries and Russia-Belarus integration (Бабич на посту).

At the same time, Russia initiated a process of "deeper integration". At the very beginning, Moscow precisely defined what is expected from the integration. So, at the end of 2018, Russian prime-minister Dmitri Medvedev declared: "I would like to emphasize that Russia is ready to continue moving towards the construction of the Union State, including the creation of a single issuing center, a single customs service, a court, an accounting chamber. In the manner provided for by the treaty establishing the Union State of 8 December 1999. In this case, it is necessary to implement a unified tax policy, pricing policy, tariff formation, and so on" (Орешко). Moscow bound the "process of the deeper integration" to further economic (financial and energy) support for Belarus to make Belarusian authority agree with new Russian conditions.

As a result, the Belarusian and Russian governmental working group had to elaborate so-called: "Program of Action of Belarus and the Russian Federation to Implement the Provisions of the Treaty on the Establishment of the Union State“. Its realization should bring the countries to closer economic integration and create a super-national economic institution. In reality, it meant that Russia would receive direct control over the Belarusian economy. The essential element of working on the "program of integration" was its secret regime and the fact that it was closed for public discussion. There were few leaks related to the content of the "Program", 
but they had been organized by the Russian President Administration and used for informational pressure on Belarus (Бутрин). Only in September 2019, the Russian newspaper "Kommersant" published an article dealing with several issues of the deeper integration. According to "Kommersant", the "Program" included:

- Unification of tax systems: it is assumed that the Union State of Russia and Belarus will adopt a single Tax Code by April 1, 2021;

- Unification of the customs' policy (up to joint customs raids, a common information system, and common customs service);

- Unification of the energy systems: the establishment of a "single regulator" for gas, oil, petroleum, and electricity market;

- Introduction of the single "Civic Code" (Бутрин).

Taking into consideration the Russian geopolitical strategy, it was evident that economic integration basis creates space for further political dependence of Belarus.

The final signing of the agreement was planned on December 7, 2019, (After all, it was postponed for an uncertain period). Meanwhile, on September 6, 2019, Belarusian prime-minister Sergei Rumas and Russian prime-minister Dmitri Medvedev paraphed the program. At the same time, Belarusian authority did not take any steps to enforce economic sovereignty and to initiate any system reforms. Lukashenko hoped that the traditional approach in the process of the negotiations with Russia (delaying and postponing signing or implementation of documents) would be effective. Another way to influence Russia was Belarus' intensive development of political relations with the West. It is supposed to prove to Moscow that Belarus can find another geopolitical alternative if Russia does not stop the pressure (Усов).

\section{Conclusions}

Nevertheless, Lukashenko's strategy failed. Russia has not ceased to exert the political, and economical pressure on Belarus, moreover, the pressure has been increased, especially after Lukashenko refused to sign "The program of actions" (Президенты России).

On December 23, Russian prime-minister Dmitri Medvedev declared: "All forms of additional support, additional forms of credit (for Belarus) 
are possible only if road maps are executed and implemented into laws" (Медведев назвал условие). Moreover, he mentioned that the key 31st road map included the introduction of the common currency and emission center, and establishing supranational political institutions of the Union State (Класковский).

So, relations between Belarus and Russia reached its critical point. It is evident that Moscow had a serious intention to complete the integration and demonstrate its geopolitical power. Medvedev's declaration clearly showed the real political goals of the Kremlin.

In its own turn Belarusian ruling elite was not ready for this situation at all, and Belarus is in a dead-end now. On the one hand, the only solution to the problem is denouncing the Union Treaty. But there is no real way out from the Union with Russia due to the far-reaching integration in the security and military sphere, and ineffective economy system, which survival depends on Russian support. Moreover, the immediate breaking of the economic links with Russia would undermine not only the economic system but also the Belarusian political regime.

On the other hand, the further process of integration anyway brings to the collapse of the Belarusian political model and could be a reason for the Lukashenko political demise.

For that moment, negotiations on "deeper integration" are suspended. One of the reasons is Putin's decision to introduce changes to the constitution. Owing to a series of manipulations, Vladimir Putin received a constitutional right to get elected as a president for two more cadencies. Nevertheless, it should be clear that Russia did not change its approach toward Belarus and other post-Soviet countries. The stability of the Russian authoritarian system depends on its ability of territorial expansion.

\section{References}

Ackermann F., Berman M., Sasunkevich O. (2017), 'A New Land: Rediscovering Agency in Belarusian History, Politics, and Society', Journal of Soviet and Post-Soviet Politics, 3(1): 22.

https://www.rbc.ru/politics/20/12/2019/5dfb7c9a9a79472930e161f2 (20.01.2020). International Monetary Fund (2016), 'Staff report for the 2016 article IV consultation-press release; staff report; and statement by the executive director for 
the republic of Belarus', IMF Country Report No.16/298. September 2016, https:/ / www.imf.org/external/pubs/ft/scr/2016/cr16298.pdf (14.11.2019).

Usov P. (2014), Powstanie, konsolidacja i funkcjonowanie reżimu neoautorytarnego na Białorusi, Warszawa.

Zakaria F. (1997) 'The Rise of Illiberal Democracy', Foreign Affairs; 76 (6): 22-43.

Бабич на посту замглавы Минэкономразвития РФ займется вопросами ин-

теграции с Беларусью, https://interfax.by/news/policy/vneshnyaya_ politika/1260225/, (20.01.2020).

Бутрин Д., Дружба налогоһ, https:/ / www.kommersant.ru/doc/4094365 (23.01.2020).

Венедиктов А., Россия как либеральная империя; будет ли А. Чубайс президентом

Pоссии?, https:/ / echo.msk.ru/programs/beseda/23475/ (18.11.2019).

ЕРС ПВО: старт, растянувшийся на годы. Военно-политическое обозрение, https:/ / www.belvpo.com/57695.html/ (10.01.2020).

Информационно-аналитический портал Союзного Государтва (1), Договор o Союзе Беларуси и России, http://www.soyuz.by/about/docs/dogovor3/ (17.11.2019).

Информационно-аналитический портал Союзного Государтва (2), Договор о создании Союзного государства, http:/ / www.soyuz.by/about/docs/dogovor5/ (17.11.2019).

Класковский А., Откровения Медведева. Россия берет Беларусь за горло единой валютой, https://naviny.by/article/20191223/1577134777-otkroveniyamedvedeva-rossiya-beret-belarus-za-gorlo-edinoy-valyutoy (25.01.2020).

Лукашенко: Беларусь готова выполнят в роль мошного моста между Россией и Евponoũ, www.tut.by. https:/ / news.tut.by/society/24637.html (14.11.2019).

Медведев назвал условие для дополнительной финансовой поддержки Беларуси, https:/ / naviny.by/new/20191223/1577123740-medvedev-nazval-usloviedlya-dopolnitelnoy-finansovoy-podderzhki-belarusi (23.01.2020).

Орешко А., Москва предлагает Минску два сиенария дальнейшей интеграици, https:/ / naviny.by/article/20181213/1544718400-moskva-predlagaet-minskudva-scenariya-dalneyshey-integracii (18.01.2020).

Официальный сайт Постоянного Коммитета Союзного Государства, https:/ / wWw.postkomsg.com/premier/ (18.11.2019).

Писарев Г., Прославившиеся" в Крыму, силовики и бывиие подчиненные. Кого nосол Бабич привез в Минск, https://news.tut.by/economics/632010.html (20.01.2020).

Пригора Г., Березовский: Лукашенко рассматривали на пост президента России, https:/ /inosmi.ru/sngbaltia/20130326/207384730.html (18.11.2019).

Смирнов Д., Вейшнория: как на Западе Беларуси появилось "новое государство", https:/ / $42 . t u t . b y / 558179$ (18.01.2020).

СПС представил проект "Либеральный империализм", https:/ /ria.ru/20041216/ 762228.html (18.11.2019). 
Суботин И., Номенклатура, глядя на Бабича, начинает задавать себе вопрос: В Беларуси появился еще один изентр силы кроме Лукашенко?, https://udf. by/news/main_news/191537-nomenklatura-gljadja-na-babicha-nachinaetzadavat-sebe-vopros-v-belarusi-pojavilsja-esche-odin-centr-sily-kromelukashenko.html, (20.01.2020).

Ткачёв И., А. Фейнберг, Счет на $\$ 100$ млрд Как Россия содержит белорусскую экономику, https://www.rbc.ru/newspaper/2017/04/03/58e026879a79471 d6c8aef30 (14.11.2019).

УсовП., Интеграционнаяловушка, https:/ / belsat.eu/ru/news/integratsionnayalovushka/ (24.01.2020).

Харитонов С., Он очень хотел попасть в Кремль". Почему у Лукашенко не получилось возглавить союз России и Беларуси, https://www.currenttime.tv/a/ lukashenko-belarus-russia-yeltsin/30117700.html (18.11.2019).

Центральная комиссии Республики Беларусь по выборам и проведению республиканских референдумов, Сообщение об итогах голосования на республиканском референдуме, 14 мая 1995 года, https:/ / web.archive.org/ web/20110720220048/http://www.rec.gov.by/refer/ref1995resdoc.html (17.11.2019).

Электронный фонд правовой и нормативно-технической документации, Соглашение между Правительством Российской Федерации и Правительством Республики Беларусь о порядке завершения строительства, использования и содержания Узла Барановичи системы предупреждения о ракетном нападении, расположенного на территории Республики Беларусь от 6 января 1995 г, http:/ / docs.cntd.ru/ document/1901903 (17.11.2019). 